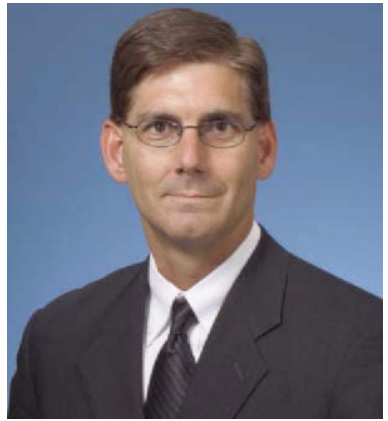

\section{0 in Review}

February is the month where we provide a report to SPIE members on the status of the journal Optical Engineering. There have been many changes in publishing over the past few years and some of these changes impact Optical Engineering. We will discuss some of these changes as we go through this report, and other aspects, such as impact factor and steps we are taking to improve the quality of Optical Engineering, were discussed in previous editorials during 2010.

The number of papers published in 2010 was 405 , which is a 12.5\% increase from 2009 as shown in Table 1. While 2009 was at a low of 360 papers, we were still below the publication levels of 2004 to 2008. If you recall from last year's status, we continue to pursue a high acceptance criteria so that the quality of the papers remains high. In fact, the acceptance statistics for the regular papers in 2010 were about the same as the statistics in 2009. The acceptance rate went from $41 \%$ to $46 \%$ to include regular and special section papers. It was the special section papers that accounted for the 2010 increase in papers published and the increase in acceptance rate. The regular paper statistics and special section paper statistics are provided in Table 2. In my opinion, the special section papers published in 2010 were of a high quality and will eventually raise the impact factor of the journal. (It should be noted that the 95 special section papers received and the 39 special section papers published does not translate

Table 1 Major statistics from 2004 to 2010 and percentage of changes from 2009.

\begin{tabular}{lllllllll}
\hline \hline & 2004 & 2005 & 2006 & 2007 & 2008 & 2009 & 2010 & $\begin{array}{l}\% \text { change } \\
\text { from 2009 }\end{array}$ \\
\hline $\begin{array}{l}\text { Number of } \\
\text { journal } \\
\text { pages }\end{array}$ & 3164 & 3750 & 3920 & 3966 & 3506 & 2842 & 3210 & $+12.9 \%$ \\
$\begin{array}{l}\text { Number of } \\
\text { technical } \\
\text { pages }\end{array}$ & 3023 & 3630 & 3802 & 3864 & 3410 & 2771 & 3097 & $+11.8 \%$ \\
$\begin{array}{l}\text { Number of } \\
\text { papers } \\
\text { published }\end{array}$ & 422 & 515 & 525 & 515 & 442 & 360 & 405 & $+12.5 \%$ \\
\hline \hline
\end{tabular}

Table 2 Regular versus special section papers, received and published, from 2004 to 2010 (including OE Letters).

\begin{tabular}{lccccccc}
\hline \hline & 2004 & 2005 & 2006 & 2007 & 2008 & 2009 & 2010 \\
\hline $\begin{array}{l}\text { Regular papers } \\
\text { received }\end{array}$ & 912 & 875 & 826 & 879 & 937 & 939 & 939 \\
$\begin{array}{l}\text { Regular papers } \\
\text { published }\end{array}$ & 318 & 478 & 525 & 500 & 442 & 360 & 366 \\
$\begin{array}{l}\text { Special section } \\
\text { papers received }\end{array}$ & 121 & 6 & 21 & 1 & 0 & 0 & 95 \\
$\begin{array}{l}\text { Special section } \\
\text { papers published }\end{array}$ & 104 & 37 & 0 & 15 & 0 & 0 & 39 \\
\hline \hline
\end{tabular}

into a high rejection rate, since many of the papers received in 2010 are for special sections in 2011.) Finally, as in the past we were more critical of $O E$ Letters submissions with a $39 \%$ acceptance rate. I will continue to work with the associate editors to ensure that $O E$ Letters maintains a higher standard of significance and originality than regular journal papers.

The first authors of the published papers came from all over the world (Table 3). The largest percentage of contributions, which come from Asia, remained high at $57 \%$ in 2010. There were significant increases in papers published from North America and Western Europe. There were decreases in papers published from Australia and South/Central America.

The SPIE Journals staff (you will find their names listed on the masthead of the journal) are some of the most professional people I have ever worked with and they are the brains and brawn behind making Optical Engineering a reality. They ensure that all manuscripts are processed fairly, that associate editors provide a timely decision path,

Table 3 Number of papers published by region of first author from 2005 to 2010.

\begin{tabular}{lrrrrrrr}
\hline \hline Region & 2005 & 2006 & 2007 & 2008 & 2009 & 2010 & $\%$ of Total \\
\hline Africa & 5 & 4 & 5 & 4 & 2 & 1 & $0.3 \%$ \\
Asia & 212 & 283 & 280 & 255 & 211 & 230 & $56.8 \%$ \\
Australia & 5 & 5 & 5 & 4 & 6 & 1 & $0.3 \%$ \\
Eastern Europe & 28 & 12 & 14 & 8 & 11 & 9 & $2.2 \%$ \\
Middle East & 10 & 15 & 7 & 10 & 12 & 11 & $2.7 \%$ \\
North America & 152 & 136 & 131 & 106 & 76 & 98 & $24.2 \%$ \\
South/Central & 3 & 2 & 4 & 5 & 9 & 1 & $0.3 \%$ \\
America & & & & & & & \\
Western Europe & 100 & 68 & 69 & 50 & 33 & 54 & $13.3 \%$ \\
Totals & $\mathbf{5 1 5}$ & $\mathbf{5 2 5}$ & $\mathbf{5 1 5}$ & $\mathbf{4 4 2}$ & $\mathbf{3 6 0}$ & $\mathbf{4 0 5}$ & $\mathbf{1 0 0 \%}$ \\
\hline \hline
\end{tabular}


Table 4 Activity of the editorial office in 2010 (all papers).

\begin{tabular}{lcc}
\hline \hline & Number & $\begin{array}{c}\% \text { change } \\
\text { from 2009 }\end{array}$ \\
\hline Reviewers solicited & 5065 & $+5.6 \%$ \\
Reviews received & 2254 & $+42.7 \%$ \\
Revised manuscripts received & 653 & $+29.3 \%$ \\
Papers returned to authors for revision & 626 & $+28.8 \%$ \\
\hline \hline
\end{tabular}

that the reader consumes a quality product, and that $O p$ tical Engineering is a journal of community service to the optical engineering constituency. They also keep me on track in executing new plans for the journal and in writing these editorials. The activity of the journals office is shown in Table 4.

There is one area where we did not do as well in 2010 as 2009 , which is time from submission to publication (see Table 5). The journals staff did a great job at keeping the production time to 2.0 months for regular papers and they reduced the production time for OE Letters to 1.2 months from 1.7 months. These times include copyediting, typesetting, author proofs, and other key steps in the publication process. However, the time to complete the initial review increased from 1.7 months to 2.2 months for regular papers and from 0.8 months to 1.7 months for $O E$ Letters. This is an area where the associate editors and I will work hard this year to shorten the review time, since turnaround time is an important publication aspect to all authors.

Finally, there were considerable changes to the board of editors in 2010. Michael Bove in the area of video and computer holography, Greg Quarles in the area of lasers and laser applications, Giancarlo Righini in the area of integrated optics, and Sergio Velastin in the area of image processing have all completed tenures as associate editors. We added Feng Chen in optical materials, Chunlei Du in optical elements,
Table 5 Journal performance.

\begin{tabular}{lllllll}
\hline \hline & 2005 & 2006 & 2007 & 2008 & 2009 & 2010 \\
\hline $\begin{array}{l}\text { Average time to complete } \\
\text { initial review (months) }\end{array}$ & 2.2 & 2.3 & 2.0 & 1.9 & 1.7 & 2.2 \\
$\quad \begin{array}{l}\text { Regular papers } \\
\text { OE Letters }\end{array}$ & 1.2 & 1.2 & 1.0 & 0.8 & 0.8 & 1.7 \\
$\begin{array}{l}\text { Average time from acceptance } \\
\text { to publication (months) }\end{array}$ & & & & & & \\
$\quad \begin{array}{l}\text { Regular papers } \\
\quad \text { OE Letters }\end{array}$ & 5.8 & 7.4 & 6.1 & 3.3 & 2.0 & 2.0 \\
$\begin{array}{l}\text { Total time in system (months) } \\
\text { not including revision }\end{array}$ & 2.3 & 2.4 & 2.8 & 2.1 & 1.7 & 1.2 \\
$\quad$ Regular papers & & & & & & \\
$\quad$ OE Letters & 8.0 & 9.7 & 8.1 & 5.2 & 3.7 & 4.2 \\
\hline \hline & 3.5 & 3.6 & 3.8 & 2.9 & 2.5 & 2.9 \\
\hline \hline
\end{tabular}

Michael Eismann in imaging, Maurizio Ferrari in integrated optics, Ofar Hadar in video and image processing, Van Hodgkin in optical measurements, Khan Iftekharuddin in image processing, and Robert Plemmons in image processing. We also began a trial program with associate editors for conferences with Will Rabinovich and Mark Mirotznick. While Eddie Jacobs is listed as the associate editor for the Student Advisory Board, he helps out with regular associate editor duties in radiometry and infrared systems, as well as with the Defense, Security, and Sensing Conference. The current list of editorial board members can be located on the SPIE website, http://spie.org/x634.xml. I would like to thank all of those who have served as associate editors. It is an important job and there is very little thanks for making sure that Optical Engineering continues to provide a valuable service to the optical engineering community.

Ronald G. Driggers Editor 